\title{
Dependability a Key Element for Achieving Competitive Advantage: A Study of Information Service Firms
}

\author{
Vikas Kumar ${ }^{1, *}$, Archana Kumari ${ }^{2}$, Jose Arturo Garza-Reyes ${ }^{3}$, and Ming Lim ${ }^{3}$ \\ ${ }^{1}$ Dublin City University Business School, Dublin City University, Dublin, ROI \\ vikas. kumar@dcu.ie \\ ${ }^{2}$ Department of Business Economics, University of Delhi, New Delhi, India \\ archana_mbe2008@yahoo.com \\ ${ }^{3}$ Centre for Supply Chain Improvement, The University of Derby, Derby, UK \\ \{J.Reyes, M.Lim\}@derby.ac.uk
}

\begin{abstract}
In the current economic climate and intense competitive environment achieving sustainable competitive advantage has become vital for any organisation's survival. Organisations around the globe are seeking ways to distinguish themselves from their competitors and win customers. This paper attempts to study the significance of sustainable competitive advantage from the information service firms' perspective. The paper argues that service firms can distinguish themselves and attain competitive advantage by performing well on operational performance elements that lead to customer satisfaction, loyalty and ultimately to profitability. Particularly, the paper empirically investigates the importance of dependability and quality in driving customer satisfaction and customer loyalty. The analysis shows that dependability is a key driver of customer satisfaction and customer loyalty. Thus, information service firms should focus more on improving the reliability of their services to achieve competitive advantage and later that may lead to a sustainable competitive advantage.
\end{abstract}

Keywords: Customer loyalty, Customer satisfaction, Competitive advantage, Dependability, Quality, Path analysis.

\section{Introduction}

In the current competitive climate, achieving sustainable competitive advantage is a key to survival for any small or large service organisation. Therefore, organisations around the globe are continuously seeking ways of improving their operational performances, quality, competitiveness, and profitability that ultimately leads to sustainable competitive advantage. It is well evident that that once dominated by manufacturing industries the economy has, nowadays, shifted more towards a service based economy. This is a result of rapid growth of services in last few decades and is evident from the contribution of services to the Gross Domestic Product (GDP) [1] of

* Corresponding author.

V. Prabhu, M. Taisch, and D. Kiritsis (Eds.): APMS 2013, Part I, IFIP AICT 414, pp. 493-500, 2013.

(C) IFIP International Federation for Information Processing 2013 
most of the developed economies such as the U.S. (80\%), UK (75\%), Japan (74\%), France $(73 \%)$ and Germany $(68 \%)$. In recent years, the information service sector has emerged as a strong contributor to the GDP with the rapid advancement in modern internet and communication technologies across the world [2]. Despite the growth, services appear not to have received sufficient attention from researchers, while manufacturing-oriented research has so far dominated [2]. In addition, there is plenty of research surrounding sustainability issues; however, customer centric view of sustainability has been seldom addressed in research [3]. In services, quality and dependability are normally regarded as critical factors that differentiate them from others. Often these are also referred as the elements of the technical service quality. How well a service firm performs on these dimensions can lead to a source of competitive advantage. Research evidences show that by performing well on customer satisfaction and loyalty dimensions, organisations can enhance their performance and achieve sustainable competitive advantage [4]. Although, the literature on sustainable competitive advantage is vast, this paper primarily focuses on the investigation of the interrelationship between dependability, quality, customer satisfaction, and customer loyalty that are source of competitive advantage. The objective of the study is also to identify whether dependability is a key driver of satisfaction and loyalty.

Research indicates that there are two critical dimensions to service performance: performance relative to operational elements and performance relative to relational elements [5]. However, service operations management views services from customer and operational perspectives [6,7]. Literature on service quality tends to advocate relational aspects and puts less emphasis on the operational aspects. This research, therefore, also attempts of fill this gap and highlights the importance of operational elements. This research emphasises that performing well on operational elements leads to satisfied and loyal customers. Operational indicators such as dependability, quality, and speed have been of interest for operations management researchers $[5,8]$. This research is primarily focused on two operational elements of the service performance-dependability and quality that have widely argued in service quality literature $[9,10,11]$. The research investigates their linkages with customer satisfaction and loyalty in a new context of information intensive services.

The rest of the paper is organised as follows. The next section provides a brief literature review around sustainable competitive advantage, operational performance elements, and their linkages. Sections 3 and 4 discuss the research objectives, research methodology, and propose the research framework that is investigated in this research. The finding of this research is discussed in section 5. Finally, conclusions and implications are discussed in section 6 . This section also proposes some future research directions.

\section{Research Background}

Service organisations are currently going through an era of rapid transformation and intense competition that continuously questions their survival. As a result, achieving sustainability is today regarded as a critical business goal by multiple stakeholders, 
including investors, customers and policymakers [11, 12]. The willingness and ability of service managers in organisation to respond to the on-going changes in economy determines whether their own organisation will survive and prosper [13]. Rapid innovation has further increased the intensity of competition and in such conditions customer satisfaction and retention has emerged as a source of sustainable competitive advantage [4]. In a resource based model competitive advantage is viewed from the perspective of 'distinctive competencies' that give a firm an edge over its competitors [14]. From service firms perspective the ability of the firm to distinguish itself from other competitors in terms of its service delivery and exceed the customer expectation level can act as a source of competitive advantage. And if the service firm continues to distinguish itself by exceeding customer expectations of service performance levels, it can lead to a sustainable competitive advantage. One of the ways the service firms can meet or exceed customer expectation is by performing well on operational performance aspects (such as quality, dependability, speed etc.) which ultimately leads to customer satisfaction and customer loyalty.

Customer satisfaction is generally measured as a gap between the customer's expectations and actual perceived services [15] whereas customer loyalty is defined as the customer's long-term commitment to repurchase and willingness to use the service repeatedly [5]. The link between customer satisfaction, loyalty, and profitability is well explained through the Service Profit Chain (SPC) framework developed by [16]. The fact that customer satisfaction is of fundamental importance and potentially offers a broad range of benefits for any organisation is well established in literature. Previous studies reveal that a satisfied customer is more likely to repurchase, leading to increased sales and market share [17, 18]. Thus, improving customer satisfaction service firms can lead to a path of sustainable competitive advantage. Eggert and Ulaga [19] pointed out that customer satisfaction is a strong predictor of behavioural variables, such as customer loyalty, word of mouth, and repurchase intentions. This was also supported in the work of [20] and others. These studies indicate a strong link between the two performance-outcome measures; customer satisfaction and customer loyalty.

Gonzalez et al. [11] highlighted the positive relationship between perceived service quality and customer satisfaction. They found that perceived service quality is an antecedent of satisfaction. Chiou et al. [21] showed that the attribute of satisfaction and interactive service quality generate overall satisfaction and trust. These studies show a strong link between customer satisfaction and service quality. This relationship between service quality and customer satisfaction can be further understood through the service concept model [2, 22]. Johnson and Sirikit [13] in their study of the Thai telecommunication industry showed that performing well on service quality dimension leads to a sustainable competitive advantage.

Another important operational indicator, dependability and its relationship to customer satisfaction and loyalty has also been addressed by several researchers, such as [20], and [23]. In a study by [23], he discussed dependability as a performance factor that affects customer satisfaction. This view was also supported in the work of [23] who, demonstrate that perceived dependability affects user satisfaction positively. Rosenzweig and Roth [24] also identified an interrelationship between dependability and quality, as they hypothesized that enhanced conformance to quality 
has a direct influence on improvements in reliable delivery. They further provided an empirical evidence of their impact in driving business performance (i.e. profitability). A number of researchers have identified dependability as a key operational indicator $[5,23,25]$. However, there is a lack of empirical evidence in literature that addresses the link between dependability, quality, customer satisfaction and customer loyalty in the information service firms. Therefore, this paper sets out a background to explore this interrelationship to assist managers to plan their service strategies and focus on the operational element of prime importance that can help firms to achieve sustainable competitive advantage.

\section{Research Objectives and Framework}

The literature review highlights operations performance indicators, particularly quality and dependability that affect customer satisfaction and loyalty. This study is a confirmatory study which aims to test the findings of service operations management and service quality literature, particularly in the context of information service settings. However, this study also looks beyond the operational performance and performance outcome link. The study emphasises that performing well on operations performance dimension can assist service firms to achieve distinctive advantage and ultimately lead to a sustainable competitive advantage. Since the study does not encapsulate any variable to measure the competitive advantage, this study can be treated as a preliminary study that primarily focuses on identifying the importance of dependability and quality that forms the foundation for achieving sustainable competitive advantage. The investigation involves assessing these relationships in two large information intensive firms operating in the UK. This research sets out to test the following in the context of information service settings:

- Dependability and quality affect customer satisfaction and customer loyalty

- Dependability is a key indicator/driver of customer satisfaction and customer loyalty

- An interrelationship exists between dependability and quality

The research framework tested in this research comprises of two critical performance indicators; quality and dependability that are usually present in a service delivery system. The literature linking these individual operational indicators and customer loyalty through mediating variable customer satisfaction is available in abundance [5,16,25]. However, empirical studies assessing this relationship in information intensive service firms are limited. The propositions derived from the framework reflect key relationships that were described in the literature review. This case study tests four prepositions:

P1: Customer Loyalty is positively correlated with Customer Satisfaction

P2: Customer Satisfaction is positively correlated with Dependability

P3: Customer Satisfaction is positively correlated with Quality

P4: Dependability and Quality are positively correlated

The next section details the methods for data collection employed in this study. 


\section{$4 \quad$ Methodology}

The paper studies two large information intensive service firms operating in the UK. The first case study is based on the data collected from a large telecommunication firm. In this research the data for the broadband installation process is collected. The second case is based on the data collected from a large utility firm operating in the UK. The longitudinal data for the telecommunication and utility firm collected through telephonic interviews comprised monthly measurements (total 48 data points) of variables considered as proxies for quality, dependability, customer satisfaction, and customer loyalty in a four-year time frame.

In this research, dependability is referred as an ability to perform the promised service dependably and accurately, including time commitments. Both the service firms studied in this research used a single scale item with the understanding that dependability means fulfilling promises including time commitment. Both the firms also did not employ SERVQUAL scale to measure the quality construct. However, the measures used by the firm resemble to some of the items of the SERVQUAL scale including the empathy, access, assurance, and responsiveness dimensions. Customer satisfaction and customer loyalty constructs were also operationalised as a single item measure. Customer satisfaction was measured as overall satisfaction with the level of services provided and customer loyalty was measured as the likelihood of recommendation of the service to others. The constructs studied in this study conform to the reliability and validity tests.

\section{$5 \quad$ Research Findings}

The correlation analysis of the first case study (telecommunication) shows a moderate and positive correlation $(0.53)$ between dependability and customer satisfaction at $\mathrm{p}$ $<0.01$ level. There was also a strong and positive correlation between customer satisfaction and customer loyalty. Correlation between quality and dependability as well as between quality and customer satisfaction was not significant. Similarly, for case II (utility) a strong and positive correlation (0.88) was found between dependability and customer satisfaction at $\mathrm{p}<0.01$ level. A strong and positive correlation was also evident between customer satisfaction and customer loyalty. Interestingly no significant correlation was found between quality and dependability as well as quality and customer satisfaction. Thus, the findings show support for the proposition 1 and 2. However, correlation analysis does not support proposition 3 and 4. To further verify the results of correlation analysis regressions were carried out. Regressions were performed to verify the findings of the correlation analysis. Regression shows that quality and dependability in total explain around $62.4 \%$ (Adj. $\mathrm{R} 2$ value) and $76.6 \%$ (Adj. R2 value) of the unexplained variance respectively for case I and II. However, only the dependability coefficient was found to be significant at $1 \%$ level. The correlation analysis results are shown in Figure 1.

Thus, the findings indicate that dependability is a key indicator of customer satisfaction and customer satisfaction is strongly linked with customer loyalty. 
However, both studies failed to provide support for propositions 3 and 4. To explore the interrelationship, i.e., causality among the variables, path analysis method was employed. The resultant path model for both cases supported the findings of correlation analysis and indicated a positive causal relationship between dependability and customer satisfaction as well between customer satisfaction and customer loyalty. Path analysis also showed that quality and customer satisfaction share a positive causal relationship thus supporting proposition 4. Additionally, it also showed that quality and dependability share a negative causal relationship that suggest that improvement in one performance indicator is only possible at the expense of the other though this further needs investigation.
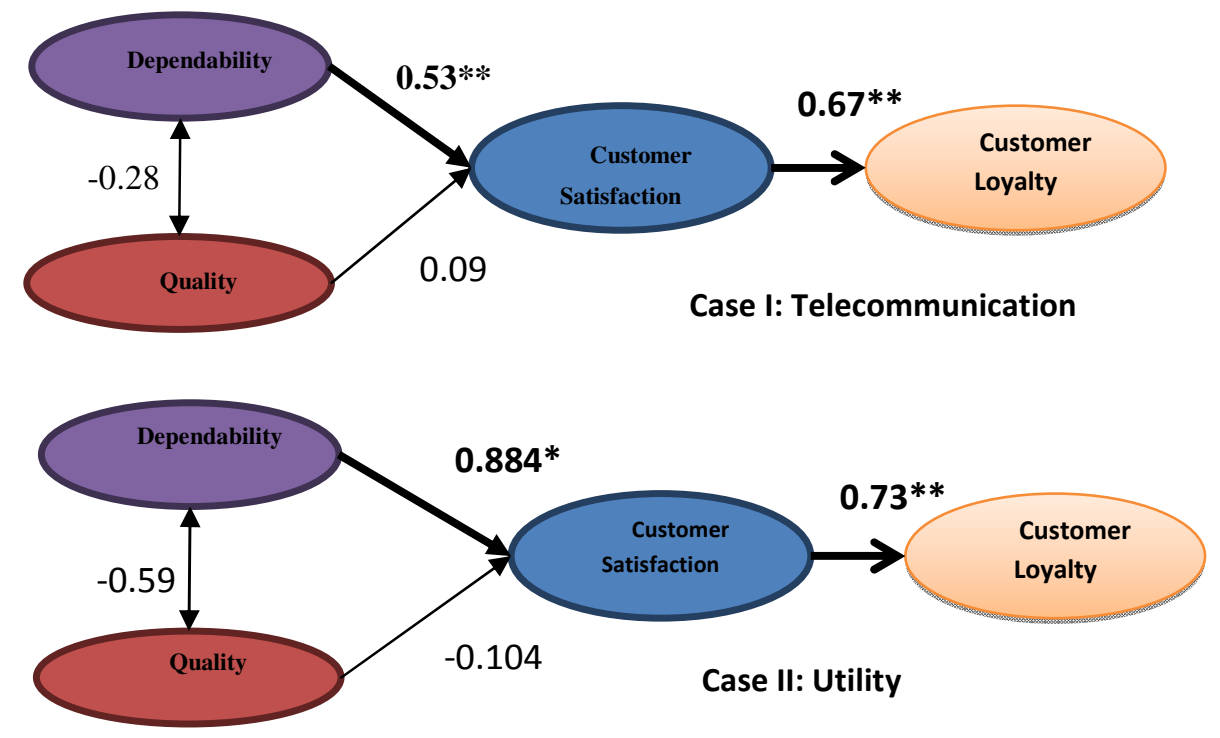

**Correlation is significant at the 0.01 level (2-tailed).

Fig. 1. Correlation analysis result of Case I \& II

\section{Conclusions and Future Research}

The paper provides a brief overview of the significance of achieving sustainable competitive advantage and highlights the importance of customer satisfaction and customer loyalty. This research also argues that for service firms performing well on operational performance elements is a key to achieving sustainable competitive advantage. The paper studies two cases from different information intensive service firms operating in the UK. The analysis of the data showed that dependability is a key driver of customer satisfaction. Both cases further investigated the relative impact of dependability and quality and shows that for information service a firm's dependability is more important as opposed to SERVQUAL literature findings, where 
traditional priority is afforded to quality. Additionally, the data analysis showed that a negative relationship exists between dependability and quality. Therefore, service firms looking to achieve competitive advantage must focus on improving their dependability/reliability of their service offerings. This is not to say that quality is not important rather it suggests that service firms should first focus on improving their dependability of the service and when a certain level is reached that meets or exceeds the customer expectation level then focus should move on improving the next operational performance element such as quality or speed while still improving dependability. In the current intense competitive environment developing a distinct competence has become a norm for survival and service firms need to differentiate themselves by using and realigning their existing resources and competencies in way their competitors cannot match. By learning to perform well on operational performance dimension can help service companies to achieve their goal of sustainable competitive advantage.

This study is limited to two case studies from the information service firms operating in the UK. For generalisation of the findings more cases are required to be studied, particularly cross-country cases. Though, this research indicates that operational performance elements are important for customer satisfaction and loyalty, and argues their importance for competitive advantage, but the research does not study any variable that measures the competitive advantage. This study is a preliminary step towards the understanding of dependability as a critical factor in achieving competitive advantage. Therefore, future research studies should be aimed at empirically studying a proxy to measure the competitive advantage together with the operational performance and performance outcome indicators.

\section{References}

1. Lovelock, C., Wirtz, J.: Services Marketing: People, Technology, Strategy, 6th edn. Pearson Prentice Hall, US (2007)

2. Kumar, V.: An Empirical Investigation of the Linkage between Dependability, Quality and Customer Satisfaction in Information Intensive Service Firms. PhD Thesis, Exeter University (2011)

3. Sheth, J.N., Sethia, N.K., Srinivas, S.: Mindful Consumption: A Customer-centric Approach to Sustainability. Journal of the Academy of Marketing Science 39(1), 21-39 (2011)

4. Verona, G., Prandelli, E.: A Dynamic Model of Customer Loyalty to Sustain Competitive Advantage on the Web. European Management Journal 20(3), 299-309 (2002)

5. Stank, T.P., Goldsby, T.J., Vicekry, S.K.: Effect of Service Supplier Performance on Satisfaction and Loyalty of Store Managers in the Fast Food Industry. Journal of Operations Management 4, 429-447 (1999)

6. Sampson, S.E.: Understanding service businesses: Applying Principles of the Unified Services Theory, 2nd edn. John Wiley \& Sons, New York (2001)

7. Sampson, S.E., Froehle, C.M.: Foundation and Implication of a Proposed Unified Services Theory. Production and Operations Management 15(2), 329-343 (2006)

8. Slack, N., Chambers, S., Johnston, R.: Operations Management, 4th edn. Prentice Hall FT, Harlow (2004) 
9. Zeithaml, V.A., Parasuraman, A., Berry, L.L.: Delivering Quality Service: Balancing Customer Perceptions and Expectations. Free Press, New York (1990)

10. Parasuraman, A.: Refinement and Reassessment of the SERVQUAL Scale. Journal of Retailing 67(4), 420-450 (1991)

11. Gonzalez, A.E.M., Comesana, R.L., Brea, F.A.J.C.: Assessing Tourist Behavioural Intensions through Perceived Service Quality and Customer Satisfaction. Journal of Business Research 60(2), 153-160 (2007)

12. Pfeffer, J.: Building Sustainable Organizations: The Human Factor. Academy of Management Perspectives 24(1), 34-45 (2010)

13. Johnson, W.C., Sirikit, A.: Service Quality in a Thai Telecommunication Industry: a Tool for Achieving Sustainable Competitive Advantage. Management Decision 40(7), 693-701 (2002)

14. Ghemawat, P.: Sustainable Advantage. Harvard Business Review, 53-58 (SeptemberOctober 1986)

15. Grönroos, C.: From Scientific Management to Service Management: a Management Perspective for the Age of Service Competition. International Journal of Service Industry Management 5(1), 5-20 (1994)

16. Heskett, J.L., Jones, T.O., Loveman, G.W., Sasser Jr., W.E., Schlesinger, L.A.: Putting the Service-profit Chain to Work. Harvard Business Review, 164-174 (March-April 1994)

17. Cronin, J.J., Morris, M.H.: Satisfying Customer Expectations: the Effect on Conflict and Repurchase Intentions in Industrial Marketing Channels. Journal of the Academy of Marketing Science 17(1), 41-49 (1989)

18. Innis, D.E., La Londe, B.J.: Customer Service: the Key to Customer Satisfaction, Customer Loyalty, and Market Share. Journal of Business Logistics 15(1), 1-27 (1994)

19. Eggert, A., Ulaga, W.: Customer Perceived Value: a Substitute for Satisfaction in Business Markets? Journal of Business and Industrial Marketing 17(2/3), 107-118 (2002)

20. Parasuraman, A., Berry, L.L., Zeithaml, A.V.: SERVQUAL: A Multiple Item Scale for Measuring Customer Perception of Service Quality. Journal of Retailing 64(1), 12-40 (1988)

21. Chiou, J.S., Droge, C., Hanvanich, S.: Does Customer Knowledge Affect How Loyalty is Formed? Journal of Service Research 5(2), 113-124 (2002)

22. Goldstein, S.M., Johnston, R., Duffy, J., Rao, J.: The Service Concept: The Missing Link in Service Design Research? Journal of Operations Management 20(2), 121-134 (2002)

23. Lai, J.Y., Yang, C.C.: Effects of employees perceived dependability on success of enterprise applications in e-business. Industrial Marketing Management 38(3), 263-274 (2009)

24. Rosenzweig, E.D., Roth, A.V.: Towards a Theory of Competitive Progression: Evidence from High-Tech Manufacturing. Production and Operations Management 13(4), 354-368 (2004)

25. Kumar, V., Batista, L., Maull, R.: The Impact of Operations Performance on Customer Loyalty. Service Science 3(2), 158-171 (2011) 